\title{
ВПЛИВ ЦИТРАТІВ МІКРОЕЛЕМЕНТІВ НА РЕПРОДУКТИВНУ ЗДАТНІСТЬ БДЖОЛИНИХ МАТОК
}

\author{
Ковальчук I. І., Кикіш І. Б., Каплуненко В. Г.
}

\section{ВСТУП}

Мінеральні елементи беруть активну участь в обмінних процесах організму бджіл. Вони регулюють окисно-відновні та анаболічнокатаболічні процеси в іх організмі ${ }^{1,2}$. Окрім того, окремі мінеральні елементи, насамперед важкі метали, навіть у незначних концентраціях (зокрема, Кадмій і Плюмбум), негативно впливають на фізіологічний стан організму та його продуктивні ознаки. Питання мінерального живлення медоносних бджіл вивчали в роботах багатьох дослідників. Однак залишається недостатньо вивченою не лише кількість, а й якість окремих компонентів живлення, зокрема вплив недостатньо вивчених мінеральних елементів у медоносних бджіл.

Як відомо, у більшості регіонів рослинна база через кліматичні та агроекологічні умови, збіднення біорізноманіття не забезпечує медоносним бджолам необхідної кількості повноцінного пилку як корму $^{3}$. Бджолярі намагаються замінити пилок різними натуральними продуктами. Заміна дефіцитного корму іншим, більш доступним, широко застосовується в годівлі різних тварин і $\epsilon$ ефективним способом балансування раціону для отримання максимальної кількості продукції. Однак у бджільництві однозначних рішень щодо підгодівлі бджіл ще немає.

Варто вказати, що для весняної підгодівлі широко використовують різноманітні відвари, настоянки різного рослинного походження, концентровані ліпідно-протеїнові та мінеральні добавки, які підвищують резистентність медоносних бджіл.

Але здебільшого звертають увагу на поповнення замінників пилку i нехтують необхідністю забезпечити раціон бджіл вітамінами, макро- i мікроелементами, що унеможливлює

${ }^{1}$ Скальный А.В. Химические элементы в физиологии и экологии человека. Москва : ОНИКС 21 век ; Мир, 2004. 216 с.

2 Скальний А.В., Рудаков И.А. Биоэлементы в медицине. Москва : Мир, 2004. 272 c.

${ }^{3}$ Kabata-Pendias, A., Pendias, H.Trace elements in soils and plants ; 3rd ed CRC Press, 2001. 403. 
збалансування живлення, або рекомендують їх мінеральні солі, які мають високу токсичність для бджіл.

Отже, виникає необхідність пошуку нових нетоксичних компонентів такої підгодівлі, у тому числі отриманих на основі новітніх технологій, що забезпечують живлення бджіл і обмін речовин у їхньому організмі на фізіологічному рівні, де макро- та мікроелементи відіграють провідну роль.

\section{1. Теоретичне обгрунтування проблеми}

Із літератури відомо, що підгодівля бджіл тільки цукровим сиропом, який майже не містить мінералів, призводить до прискореного старіння бджіл і дефіциту протеїну в їх організмі ${ }^{4,5}$. Це впливає на розвиток глоткових залоз, що відповідають за інвертування цукрів і вироблення маточного молочка, а також на функціональний стан жирового тіла, в якому нагромаджуються резервні поживні речовини організму бджоли. Тому ведеться науковий i практичний пошук із використання у критичні періоди живлення бджіл ессенціальних мікроелементів, що суттєво впливають на життєдіяльність їхнього організму, або роль яких у цих комах не з'ясовано.

Численні дослідження показали, що за недостатнього надходження мікроелементів до організму спостерігається порушення обмінних процесів, котрі призводять не тільки до різкого зниження їхньої життєдіяльності, а й до розладів, які можуть зумовлювати їх загибель ${ }^{6,7}$. Біологічна активність деяких мікроелементів значною мірою визначається тим, що вони входять до складу структур організму, зокрема до складу ензимів і гормонів.

Установлено, що в каталазі міститься Ферум, у карбонгідразі Цинк, інсуліні - Кобальт і Нікель. Цим і пояснюється зв'язок мікроелементів із вітамінами, комплексна дія яких відіграє важливу роль в організмі.

Мінеральні речовини в організмі тварин використовуються як структурний матеріал і як компоненти багатьох вітамінів, гормонів та

${ }^{4}$ Jeliazkova, I., Dinkov, D., Rusev, V., Vashin, I. Effect of feeding bees with sugar solution (1:1) and Isosweet on some qualitative parameters of Honey. Agrarian sciences Trematology. 2002. № 2. P. 300-303.

5 Шамро Л.П., Шамро Т.М. Біологічні особливості робочих бджіл за умов зимівлі бджолиних сімей на різних кормах. Вісник Полтавської державної аграрної академії. 2013. № 2. С. 70-72.

6 Скальная М.Г., Дубовой Р.М., Скальный А.В. Химические элементы микронутриенты как резерв восстановления здоровья жителей России. Оренбург, 2004. 239 c.

7 Кучинский М.П. Биоэлементы и сохранение здоровья и продуктивности животных. Минск, 2006. 264 с. 
ензимів, забезпечуючи їхню фізіологічну функцію та необхідну інтенсивність обміну речовин. Від наявності тих чи інших макроі мікроелементів залежать інтенсивність перетворення корму на енергію і використання поживних речовин для побудови тканин.

Установлено велике значення мінеральних компонентів корму для нормальної життєдіяльності організму комах. Мінеральні компоненти кормової рослини відіграють важливу роль у функціонуванні карбонатно-бікарбонатної буферної системи регуляції кислотно-лужної рівноваги в органах травлення і калій-гістидин-глютамінової системи в гемолімфі бджіл ${ }^{8,9,10}$.

Формування цих систем значною мірою залежить від нормального їх постачання мінеральними елементами 3 корму. Порушення роботи буферних систем унаслідок нестачі мінеральних речовин у кормі знижує життєздатність організму, оскільки призводить до виникнення некомпенсованого ацидозу ${ }^{11}$. Зміни хімічного складу рослин за цими параметрами чи перехід на нову кормову рослину супроводжуватимуться зсувом ферментативної діяльності кишечнику i, таким чином, пригнічуючим впливом на ріст і розвиток комах.

За утримання бджіл у лабораторних умовах і годівлі тільки розчином цукру максимальна тривалість життя становила 19 діб, тоді як із додаванням різних комбінацій мінеральних речовин за використання суміші солей фосфорнокислого калію із сірчанокислим магнієм - 26 діб, які отримували в підгодівлю морську сіль ${ }^{12}$.

Значно довше зберігала життєдіяльність група бджіл, цукровий сироп яких містив кормову добавку з такими елементами: $\mathrm{Na}, \mathrm{P}, \mathrm{Fe}$, $\mathrm{Mn}, \mathrm{Cu}^{13}$. Група бджіл, яка отримувала цукровий сироп, пергу і цю мінеральну кормову добавку, зберігала життєдіяльність 58 діб, що на $5,1 \%$ є більшим від групи, яка не отримувала добавки.

8 Федорук Р.С., Ковальчук I.І., Гавраняк А.Р. Фактори формування імунітету медоносних бджіл. Біологія тварин. 2009. Т. 11(1-2). С. 83-90.

9 Glinski, Z., Grzegorczyk, K. Hemolymph proteins of the honeybee (Apis mellifera L.) from apiaries differing by the level of pollution with heavy metals. Ann. UMCS. DD. 1995. V.50. P. 241-248.

${ }^{10}$ Zidorova, K.A., Kalashnikov, M.V. Mineral composition of the hemolymph of bees in the brood Varroa. Beekeeping. 2014. V. 2. P. 22-23.

11 Губайдуллин Н.М. Стимулирующие подкормки, аэроионизация и продолжительность жизни пчел. Пчеловодство. 2008. № 10. С. 12-13.

${ }_{12}$ Шагун J.А. Минеральные подкормки и физиологическое состояние пчел. Пчеловодство. 1982. № 8. С. 15-16.

13 Жулай В.С. Особливості білково-міінерального складу меду та біохімічне обгрунтування комплексної кормової добавки : автореф. дис. ... канд. с.-г. наук : 06.02.04. Київ, 2000. 22 с. 
В організмі комах найбільш поширеним елементом $є$ Кальцій, максимальна кількість якого міститься в мальпігієвих судинах і епітелії середньої кишки. Установлено, що в гемолімфі личинок комах міститься 0,3\% Кальцію. Високий вміст Кальцію пояснюється нагромадженням цього елементу в мальпігієвих судинах і жировому тілі $^{14}$. Він необхідний для скелетоутворення, синтезу білків, органічних кислот, нейтралізації кислот у реакціях обміну, активування ферментів (трипсину, трифосфатази тощо), входить до складу хітинового покриву. Кальцій регулює процеси формування медіаторів, що важливо для нейрофізіології комах.

Необхідним для росту личинок комах $є$ також Магній ${ }^{15}$. Кальцій $\mathrm{i}$ Магній завжди містяться у секретах кишечнику комах. Уміст Магнію в рослинах становить близько $0,2 \%$ сухої маси. Особливо багато Магнію в молодому листі і генеративних органах. Близько 10,0-12,0\% Магнію входить до складу хлорофілу. Магній підсилює синтез ефірних масел, запобігає окисненню аскорбінової кислоти. Нестача Магнію призводить до порушення фосфорного, білкового і вуглеводного обміну. Уміст Магнію в тілі тварин становить приблизно 0,04\% від сухої маси. В організмі тварин він тісно зв'язаний із Кальцієм i Фосфором, $\epsilon$ активатором фосфатів і бере участь у вуглеводному обміні ${ }^{16}$.

Фосфор як макроелемент $є$ складовою частиною білків і ліпідів, активує ферментативні процеси, що має велике фізіологічне значення для проміжного обміну білків, жирів, вуглеводів і вітамінів. Установлено позитивний вплив на розвиток розплоду медоносних бджіл Фосфору, який приймає участь в обміні вуглеводів, проте вміст його у цукровому меді в 10 разів нижчий, аніж у квітковому. Унаслідок цього зменшується кількість енергії, що вивільняється в організмі під час обмінних реакцій у вигляді потенційної хімічної енергії фосфорних сполук ${ }^{17}$.

Основна фізіолого-біохімічна дія іонів мікроелементів як каталізаторів в біоорганічних комплексах полягає у тому, що вони переводять у збуджений стан електрони комплексної біоорганічної системи. Остання виникає в результаті від'ємного індукційного ефекту. Ці фізико-хімічні реакції знижують енергію активації всієї взятої

14 Abenavoli A., Montagna M., Malgaroli A. Calcium: The common theme in vesicular cycling. Nature Neurosei. 2001. V. 4(2). P. 117-118.

${ }^{15}$ Winston Mark L. The Biology of the Honey Bee. London : Harvard University Press, 1991. $281 \mathrm{p}$.

16 Лебедев В.И., Билаш Н.Г. Питательная ценность кормов и подкормка семей. Пчеловодство. 1995. № 1. С. 16-20.

17 Самотин В. Профилактика нарушения обмена микроэлементов у животных. Москва : Колос, 1981. 143 с. 
системи, що дає можливість для більш інтенсивного перебігу в природних умовах надзвичайно складних біохімічних процесів ${ }^{18}$.

Що стосується дії малих концентрацій мікроелементів, в яких вони беруть участь, то $є$ підстави вважати, що мікроелементи у формі внутрішніх комплексів ініціюють ланцюговий процес послідовних реакцій. У цьому процесі утворюється низка вільних радикалів, з яких тільки перший виникає під впливом мікроелементів, а в подальших стадіях реакції мікроелементи вже не беруть участі, оскільки ланцюгова реакція сама створює умови, необхідні для виникнення однієї ланки за другою без участі мікроелементу ${ }^{19,20}$.

Макро-, мікроелементи відіграють важливі функції в процесах формування м'язових волокон, тканин та органів бджіл, які виконують надзвичайно велику роботу під час перенесення нектару та пилку. Так, зокрема, для м'язів потрібен Магній, який сприяє приєднуванню актину до активних центрів міозину. Найвищий вміст Магнію спостерігається влітку, зокрема у серпні, і становить 438,7 мг/100 г сухої речовини. Дещо більшу кількість Магнію, у 1,6 рази, містить хітин бджоли ${ }^{21}$.

Важливим елементом для бджіл $є$ Кобальт, що входить у цианкобаламін, який присутній у цукровому сиропі, підвищує синтез м'язових білків. Кобальт виконує важливу функцію в обмінних i біологічних процесах, позитивно впливає на ріст і розвиток бджолиної сім’і, іiі життєздатність та продуктивність. Використання Кобальту у підгодівлі бджолиних сімей сприяє підвищенню яйценосності бджолиних маток, що, відповідно, зумовлює збільшення кількості виведеного розплоду ${ }^{22,23}$. Вивчаючи вплив Кобальту на організм бджіл, хворих на нозематоз, установлено збільшення рівня білків у гемолімфі за рахунок зменшення альфа-глобулінів, що може свідчити про підвищення імунобіологічної активності організму ${ }^{24}$.

18 Морозова Л.М. Химические элементы в организме человека: справочные материалы. Архангельск : ПГУ, 2001. 45 с.

19 Скальный А.В. Микроэлементозы человека (диагностика и лечение). Практическое руководство. Москва, 2001. 96 с.

20 Скальный А.В. Микроэлементы: бодрость, здоровье, долголетие. Москва : Эксмо-Пресс, 2010. 288 с.

${ }^{21}$ Jeliazkova, I., Dinkov, D., Rusev, V., Vashin, I. Effect of feeding bees with sugar solution (1:1) and Isosweet on some qualitative parameters of Honey. Agrarian sciences Trematology. 2002. V. 2. P. 300-303.

22 Буртов Б.Я. Влияние кобальта на размножение пчел. Сельское хозяйство Северного Кавказа. 1958. № 2. С. 77-79.

${ }_{23}^{23}$ Буртов Б.Я. Кобальт и продуктивность пчел. Пчеловодство. 1961. № 10. С. 22.

24 Авцын А.П., Жавронков А.А., Рим М.А. Микроэлементозы человека, этиология, классификация, органопатология. Москва : Медицина, 1991. 496 с. 
Доведено, що в районах, де в організмі бджіл і в пилку знижений рівень Кобальту, широко поширений європейський гнилець. Уведення Кобальту в дозі 2 мл на 1 л цукрового сиропу при захворюванні бджіл європейським гнильцем, стимулює мезодермальні зародки личинок, а також збільшення кількості гемоцитів у бджіл на всіх стадіях розвитку. Спостерігається збільшення споживання личинками корму під час уведення Кобальту в раціон. Їхня маса була більшою, ніж маса личинок такого ж віку в контрольних групах, які не отримували підгодівлю мікроелементом.

Додавання до корму Кобальту впливало не лише на живу масу личинок, а й на їх розмір. Сім'ї дослідних груп вирощували особин із довшими хоботками, більшими розмірами крил і хітинових частин черевця. У цих бджіл були більше розвинуті глоткові залози. Під час отримання Кобальту з кормом збільшувалася тривалість життя комах, які утримувалися в ентомологічних садках ${ }^{25}$.

Роботи В.Г. Голоскокова ${ }^{26}$ показують, що за додавання до цукрового сиропу солей Кобальту в мікродозах збільшується кількість розплоду в сім'ях і підвищується їхня продуктивність. Іншими дослідженнями встановлено, що Кобальт позитивно впливає на синтез вітаміну $\mathrm{B}_{12}$, максимальний час його синтезу становить 96 годин ${ }^{27,28}$, а також інтенсифікує процеси перекисного окислення ліпідів ${ }^{29,30}$.

Очевидно, залежно від індивідуальних особливостей організму бджіл Кобальт викликає збільшення вмісту загального протеїну в одних випадках за рахунок зростання бета- і гамма-глобулінів, а вміст альфаглобулінів при цьому знижується; в інших випадках - за рахунок збільшення альбумінів, бета- i гамма-глобулінів 3 одночасним зниженням альфа-глобулінів, що свідчить про підвищення

${ }^{25}$ Пашаян С.А., Столбов Н.М. Кормовые добавки для пчел. Пчеловодство. 2008. № 7. C. 14-15.

${ }^{26}$ Голоскоков В.Г. Влияние микроэлементов на морфолого-физиологические показатели и продуктивность пчел. Ульяновск, 1981. С. 10-14.

${ }^{27}$ Anderson S.P.T. Nickel and cobalt: Their physiological action on the animal organism. J. Anat. Physiol. 1983. V. 17. P. 89-123.

${ }^{28}$ Nemery, B., Lewis, C.P.L., Demedts, M. Cobalt and possible oxidant-mediated toxicity. Sci. Total Environ. 1994. V. 150. P.57-64.

${ }_{29}$ Турко Я.І. Вплив нанокобальту на антиокислювальної системи організму щурів за гострого токсикологічного експерименту. Науковий вісник Львівського національного університету ветеринарної медицини та біотехнологій ім. 3.С. Гжииького. 2015. Т. 17. № 1(61). С. 194-200.

${ }^{30}$ Ушкалов В.О., Турко Я.І. Стан антиокислювальної системи організму щурів за дії нанокобальту в хронічному токсикологічному експерименті. Науковий вісник Львівського національного університету ветеринарної медицини та біотехнологій імені С.3. Гжицького. 2016. Т. 18. № 1(65). С. 238-243. 
імунобіологічної активності організму ${ }^{31}$. Кобальт виконує важливу функцію в обмінних і біологічних процесах, позитивно впливає на ріст і розвиток бджолиної сім’ї, iï життєздатність та продуктивність.

За механізмом своєї біологічної дії Нікель виявляє помітну схожість 3 іншими 3d-елементами - Ферумом і Кобальтом. В організмі він відіграє важливу біологічну роль: входить до складу гетероциклічних і фосфатних сполук ДНК і РНК, бере активну участь у стабілізації нуклеїнових кислот, зберігає структуру рибосом і захищає їх від денатурації. Установлено, що він впливає на вуглеводний обмін і окисні процеси в організмі ${ }^{32}$. Нікель $\epsilon$ активатором таких ензимів, як аргіназа, карбоксилаза та ін., а також бере безпосередню участь у регуляції синтезу і секреції гормонів аденогипофізу.

Нікель також бере участь у регуляції метаболізму гему в печінці і нирках, індукуючи активність гемоксигенази. Вивчено вплив Нікелю і Кобальту на систему комплементу ${ }^{33,34}$. Інкубація гепаринізованої плазми з Нікелем у концентрації, нижчій 100 мкМ, стимулювала конверсію С3 до C3b в чотири рази швидше, ніж Магній, який $є$ природним кофактором в активації альтернативного шляху. Однак підвищення концентрації Нікелю більше 0,5 мМ пригнічувало цей процес.

Фізіологічна роль більшості мікроелементів вивчена, тоді як вплив Германію на обмін речовин, життєві функції в організмі тварин, у т. ч. бджіл, досліджено недостатньо. Не з'ясовано фізіологічний уміст цього елемента в компонентах харчування бджіл та їхньої продукції. Не вивчено механізми позитивних ефектів на ріст і розвиток личинок бджіл, їхні відтворювальні та продуктивні якості. Водночас аналіз літератури показує, що Германій володіє широким спектром біологічної дії, запобігає старінню і загибелі клітин організму та сприяє виведенню з організму токсинів і нівелює негативний вплив чинників зовнішнього середовища ${ }^{35,36}$.

31 Роль мікроелементів у життєдіяльності тварин / М.О. Захаренко та ін. Ветеринарна медицина Украӥни. 2004. № 2. С. 13-16.

${ }^{2}$ Белецкий Е.М., Кулибаба Р.А., Владыкин К.П. Никель. Польза и вред для живых организмов. Вісник ЦНЗ АПВ Харківської області. 2012. № 12. С. 263-283.

33 Aboud, F., De Pasquale, C., Sinacori, A., Massi, S., Conte, P., Alonzo, G. Palynological, physico-chemical and aroma characterization of Sicilian honeys. Journal of ApiProduct and ApiMedical Science. 2011. V. 3(4). P. 164-173.

${ }^{34}$ Alaux, C, Ducloz, F, Crauser, D, Le Conte, Y. Diet effects on honeybee immunocompetence. Biology Letters. 2010. V. 6. P. 562-565.

35 Miracle Cure Organic Germanium. URL: http://www.organicgermanium.net/ images/dr_asai_book.pdf.

36 Shyy Hwa Tao Hazard Bolger M. Assesment of Germanium supplements. Regulatory toxicology and pharmacology. 1997. V. 25. P. 211-219. 
Цей елемент відіграє важливу роль у формуванні резистентності організму. Установлено, що органічний Германій сприяє індукції гамма-інтерферонів із пригніченням процесів розмноження клітин, які швидко діляться. Органічні солі Германію також активують імуноспецифічні клітини (Т- кілери). Доведено, що стимулюючу дію Германію через інтерферони на рівні організму зумовлюють його імуномодулюючі і радіозахисні функції. Разом із тим Германій має яскраво виражену здатність доставляти кисень до окремих клітин організму та забезпечувати його взаємодію з іонами водню. В основі дії органічного Германію під час взаємодії його 3 іонами $\mathrm{H}+$ лежить реакція дегідрогенізації ${ }^{37}$.

Тому активізація фізіологічних можливостей медоносних бджіл згодовуванням органічних солей мікроелементів $є$ безпечною альтернативою, яку може розумно використовувати людина без шкоди бджолам для підвищення життєздатності та продуктивності їхніх сімей. Індивідуальний підхід до особливостей певних періодів бджолярського сезону із застосуванням різних схем підгодівлі поживними речовинами i стимуляторами може стати запорукою ефективної адаптації бджіл і підвищення їх продуктивності та репродуктивної здатності бджолиних маток. Інтенсивність вирощування розплоду є важливим складником не лише процесів життєдіяльності сім'ї, а й виживання бджіл у цілому. Передусім на ці процеси впливає бджолина матка, але iii функція залежить від впливу комплексу зовнішніх і внутрішніх чинників, тобто від періоду, сезону, погодних і медозбірних умов, стану гнізда, чисельності особин у гнізді, породи та багатьох інших. Однак кожний окремий із них може мати позитивний або негативний вплив на темпи вирощування розплоду у гніздах сімей ${ }^{38,39,40}$.

Відомо, що робочі бджоли регулюють інтенсивність роботи матки ${ }^{41}$. За сприятливих умов вони посилюють вирощування розплоду, а за невідповідних - змушують матку зменшити або припинити відкладання яєць. Відзначено, що завдяки інтенсивності та кількості спожитого маточного молочка матка спроможна генерувати різну кількість яєць.

${ }^{37}$ Jain K.K. Nanomedicine: application of nanobiotechnology in medical practice. Med. Princ. Pract. 2008. V. 17. № 2. P. 89-101.

${ }^{38}$ Кодесь Л.Г., Пулинец Е. . Слагаемые качества маток. Пчеловодство. 2004. № 5. С. 14-15.

${ }^{39}$ Кодесь Л.Г., Шаров М.А., Коптева Е.Н. Выращивание пчелиного и трутневого расплода. Пчеловодство. 2012. № 6. С. 18-19.

${ }^{40}$ Liviu A.M., Otilia B., Melinda T. The Effect of Plant Supplements on the Development of Artificially Weaken Bee Families. Animal Science and Biotechnologies. 2010. V. 43(1). P. 457-503.

41 Левченко I.А. Стосунки між матками і робочими бджолами. Украӥнський пасічник. 1999. № 3. С. 10-11. 
Експериментально доведено ${ }^{42,43}$, що кількість бджіл під впливом тих чи інших чинників змінюється. Шляхом посилення чи ослаблення догляду, а також підгодівлі бджоломатки бджоли регулюють іiі яйценосність ${ }^{44,45}$. Установлено, що кількість спожитого маткою молочка безпосередньо впливає на процес оогенезу ${ }^{46}$.

Регулювання яйценосності маток у бджолиній сім’ї зумовлене потребами відтворення нових іiї генерацій і відбувається за дії багатьох чинників. Реагуючи на зовнішні і внутрішні подразники, робочі бджоли створюють оптимальні умови для розвитку багатовекторного регулювання процесів накопичення і споживання корму, вирощування розплоду, розбудови гнізда.

Вплив мікроелементів як на загальні процеси метаболізму цілого організму бджолиних маток, так і на всі відділи репродуктивної системи визначатиметься ендогенним впливом. Найбільш відповідальним і визначальним відділом будуть ооцити. Екзогенна регуляція овогенезу природно регламентується сезоном року. Щодо мікроелементної регуляції овогенезу, то тут важливе місце буде мати їх вплив на підщелепові залози робочих бджіл, відповідальних за якісний і кількісний склад секрету, який згодовується бджолиній матці для стимуляції та підтримки інтенсивності оогенезу ${ }^{47}$.

Розвиток i продуктивність бджолиної сім'ї залежать від кліматичних умов та медозбору. У тропіках вони мають змогу збирати корм і відтворювати нащадків протягом року ${ }^{48,49}$. У зонах із холодними зимами життєві процеси бджолиної сім'ї змінюються відповідно до пори року. Особливості клімату й розвитку медоносних рослин у нашій країні зумовлюють певну періодичність діяльності бджолиних сімей: кілька місяців вони перебувають у стані зимового спокою.

${ }^{42}$ Toth A., Kantarovich L.S., Meisel A.F., Robinson G.E. Nutritional status influences socially regulated foraging ontogeny in honey bees. Journal of Experimental Biology. 2005. V. 208. P. 4641-4649.

${ }^{43}$ Toth A.L., Robinson G.E. Worker nutrition and division of labour in honeybees. Anim. Behav. 2005. V. 69. P. 427-435.

${ }^{44}$ Biesmeijer J.C., Klaus Hartfelder K., Imperatriz-Fonseca V.L. Stingless bees: biology and management. Apidologie. 2006. P. 121-123.

${ }^{45}$ Bobiş O., Mărghitaş L.A., Moise A., Tofalvi M., Dezmirean D. Biologically active compounds from different herbs used as additive in honeybee feeding. USAMV Cluj Bull. 2009. V. 66(1-2). P. 231-236.

${ }^{46}$ Пшеславський А. Не только количество, но и качество пчел определяет успех в пчеловодстве. Пасічник. 2009. № 7(64). С. 19-21.

${ }^{47}$ Heifetz Y. The Drosophila seminal fluid protein Acp26Aa stimulates release of oocytes by the ovary. Curr. Biol. 2000. V. 10. P. 99-102.

${ }_{48}$ Аветисян Г.А., Черевко Ю.А. Пчеловодство. Москва : Академия, 2001. 320 с.

${ }^{49}$ Zhelyazkova I. Honeybees - bioindicators for environmental quality. Bulg. J. Agric. Sci. 2012. V. 18. P. 435-442. 
За даними В.А. Нестерводського, безльотний період життя бджолиної сім’і у більшості областей України становить від 120 до 160 діб ${ }^{50}$. У крайніх північних районах розведення бджіл, у Сибіру він триває до семи місяців. Період активної життедіяльності бджіл у цих районах, відповідно, скорочується. Найсильніша і найбільш продуктивна сім'я у червні та липні, коли цвіте багато рослин, добре виділяється нектар, велика тривалість світлового дня. Найбільша тривалість льотної роботи бджіл протягом доби становить 17 год. 30 хв. Якщо нектару багато, сім'ї заготовляють за день по 8-10, а за винятково сприятливих умов - понад 20 кг корму. Перед літнім медозбором у вуликах виплоджується багато бджіл, добова яйцекладка маток досягає 1500-2000 яєць. Проявляється інстинкт розмноження сімей - роїння, перед початком якого бджоли вирощують трутнів та маток. Саме цим життєдіяльність бджолиної сім'ї влітку відрізняється від іії зимового спокою ${ }^{51,52}$.

Від стану зимового спокою до активної діяльності сім'я переходить поступово. Ще в період зимівлі матка після 4-5-місячної перерви починає відкладати яйця. У комірках найтеплішої частини гнізда, де температура досягає $34-35^{\circ} \mathrm{C}$, щодоби 3'являється по кілька десятків яєць. Потім добова яйцекладка збільшується до кількасот штук.

Наявність розплоду активізує діяльність бджіл. Вони більше споживають корму, виділяють молочко, годують личинок кашкою. Однак розвиток сімей наприкінці зими стримується тим, що бджоли залишаються відносно малоактивними, вони ще не спорожнилися від неперетравлених решток. Розплід займає лише центральну частину 2-3 стільників ${ }^{53,54}$.

Для весняного розвитку сім'ї велике значення мають принесення свіжого нектару й пилку, розміщення вуликів у затишних місцях, утеплення й зменшення гнізд. Матка збільшує інтенсивність відкладання яєць - за добу відкладає по 500-1000 шт. Проте кількість бджіл у сім'ї не збільшується, а протягом першого місяця після очисного обльоту навіть дещо зменшується. Однак у ній інтенсивно

${ }^{50}$ Нестерводський В.А. Організація пасік і догляд за бджолами. Київ : Урожай, 1966. $396 \mathrm{c}$.

${ }^{51}$ Kiheung, Ahn, Xianbing, Xie, Joseph, Riddle, Jeff, Pettis, Zachary, Y. Huang. Effects of Long Distance Transportation on Honey Bee Physiology. Psyche. 2012. V. 29. P. 9.

${ }_{52}$ Cebotari, V., Toderaş, I., Buzu, I., Rudic, V., The role of „Apispir+Zn” biostimulator in increasing of productivity of Apis mellifera bee colonies. Scientific Papers. Series Animal Science. 2013. V. 59. Р. 103-107.

53 Брандорф А.З., Ивойлова М.М. Яйценосность маток в оценке медопродуктивности и зимостойкости семей. Пчеловодство. 2012. № 6. С. 16-18.

54 Дружбяк А. Якість зимівлі бджолиних сімей. Украӥнський пасічник. 2008. № 1 . С. 25 . 
оновлюється склад робочих особин: старі бджоли восьмимісячного віку відмирають, а молоді виводяться. Останні більш енергійно годують розплід, літають, виділяють віск, збирають і переробляють нектар. Чим раніше виведуться молоді бджоли і чим більше їх виведеться, тим краще підготується сім'я до медозбору ${ }^{55}$.

Переважна більшість дослідників вивчала відтворну здатність маток за дії одного або декількох чинників ${ }^{56,57}$. Вони не здійснювали комплексних досліджень, які 6 сприяли розширенню наукових положень 3 обгрунтування дії підгодівлі на процеси, що пов'язані 3 вирощуванням розплоду у гніздах бджолиних сімей.

Метою нашої роботи було дослідити стимулюючий вплив мінеральної добавки на основі цитратів Co, Ni та Ge на інтенсивність яйцекладки бджолиних маток і силу бджолиної сім'ї.

\section{2. Матеріал та методи досліджень}

Дослідження проведено у два етапи на медоносних бджолах карпатської породи, які утримувалися у вуликах-лежаках. Бджолосім’ї перевірялися щодо інфекційних та інвазійних захворювань і були благополучні стосовно цих захворювань. Дослідження проводили відповідно до положень «Загальних етичних принципів експериментів на тваринах», ухвалених Першим національним конгресом із біоетики (Київ, 2001 р.) та «Свропейської конвенції про захист тварин, що використовуються для експериментальних та інших наукових цілей» (Страсбург, 1986 р.).

Перший етап проведено на приватній пасіці с. Кореличі Перемишлянського району. Для проведення дослідження на пасіці було відібрано п'ять груп бджолиних сімей, по три бджолосім'ї-вулики у кожній. Метою дослідження було вивчити вплив згодовування бджолиним сім'ям у весняний період комплексної вуглеводної добавки 3 цитратами кобальту та нікелю на інтенсивність яйцекладки бджолиних маток.

Для проведення дослідження на пасіці було відібрано п’ять груп бджолиних сімей, по три бджолосім’ї-вулики у кожній. I контрольна -

${ }^{55}$ Панков Д.М. Комплексный подход к содержанию пчел. Пчеловодство. 2013. № 6. С. 12-13.

${ }^{56}$ Сафиуллин Р.Р. Совершенствование технологии содержания и использования пчелиных семей в условиях Татарстана : автореф. дис. ... канд. с.-х. наук. Рыбное, 2005. $28 \mathrm{c}$.

57 Дегтерев В.Г. Яйценоскость пчелиных маток и температурный режим в гнезде кассетных ульев, установленных в кочевом павильоне. Пчеловодство холодного $u$ умеренного климата : материалы IV Международной научно-практической конференции. Псков, 2016. С. 23-26. 
умови стаціонарного утримання 3 підгодівлею 0,3 л/тиждень/сім'ю цукрового сиропу, II група - за аналогічних умов із підгодівлею цукровим сиропом із додаванням 2 мг Ni у вигляді цитрату, III група за аналогічних умов підгодівлі 3 додаванням цитрату кобальту в дозі 2 мг $\mathrm{Co}^{2+}$; IV група - за аналогічних умов із додаванням цитратів нікелю в дозі 1 мг $\mathrm{Ni}^{2+}, \mathrm{V}$ група - за аналогічних умов із підгодівлею цукровим сиропом із додаванням цитратів кобальту в дозі 2 мг $\mathrm{Co}^{2+}$ та нікелю в дозі $1 \mathrm{мг} \mathrm{Ni}^{2+}$ упродовж місяця.

Метою другого етапу було вивчити вплив випоювання цитратів Со i $\mathrm{Ge}$ у весняний період на репродуктивну здатність бджолиних маток. Підгодівлю бджолиних сімей проводили за допомогою внутрішньогніздових годівниць. Дослідження були проведені на чотирьох групах бджолосімей, аналогів за масою бджіл, силою сім’ї, віком матки, по три сім’ї у кожній групі. Бджоли контрольної (I) групи отримували у весняний період підгодівлю $350 \%$ цукрового сиропу в кількості 300 мл/сім’ю/тиждень. Друга група бджіл (дослідна) - додатково 3 300 мл цукрового сиропу отримувала 30 мкг Со у вигляді цитрату, III група - 3300 мл цукрового сиропу отримувала 60 мкг Ge у вигляді цитрату, IV група - 3300 мл цукрового сиропу отримувала 30 мкг Со цитрату та 60 мкг Ge у вигляді цитрату. Тривалість випоювання сиропу і цитратів Сo i $\mathrm{Ge}$ - чотири тижні.

Показники інтенсивності яйцекладки бджолиних маток визначали методом підрахунку кількості печатного розплоду з використанням рамки - сітки 3 квадратами $5 \times 5$ см. Стандартний стільник цієї системи вуликів вміщує 40 квадратів із кожної з боків, окремий квадрат якої містить 100 бджолиних комірок. Підрахунок проводять безпосереднім накладанням рамки-сітки на стільники зі зрілим запечатаним розплодом 3 інтервалом у 12 діб, оскільки бджолиний розплід знаходиться у запечатаному стані 12 діб. Підрахувавши суму комірок усіх квадратів за один промір та поділивши цю кількість на 12, отримували показник інтенсивності середньодобової яйцекладки бджолиних маток ${ }^{58}$.

Статистичну обробку отриманих результатів проведено 3 використанням комп'ютерної програми Microsoft EXCEL iз визначенням середніх величин $\mathrm{M}$, їхніх відхилень $\pm \mathrm{m}$ i ступеня вірогідності міжгрупових різниць із використанням критерію Стьюдента (p).

${ }^{58}$ Методологія та організація наукових досліджень у тваринництві : посібник / за ред. І.І. Ібатулліна, О.М. Жукорського. Київ : Аграрна наука, 2017. 328 с. 


\section{3. Інтенсивність яйцекладки бджолиних маток за весняної підгодівлі цитратами Со і $\mathrm{Ni}$}

Установлено, що уведення бджолиним сім'ям цитратів Со і $\mathrm{Ni}$ до сиропу весняної підгодівлі викликало підвищення інтенсивності яйцекладки бджолиних маток дослідних груп (табл. 1).

У підготовчий період кількість відкладених яєць кожною бджолиною маткою контрольної та дослідних груп за 12 діб обліку коливалася від 4753 (III гр.) до 5912 (V гр.) проти 5387 яєць у контролі. Упродовж перших 12 діб дослідного періоду їх кількість збільшилася до 9764 (41,9\% від контролю) у II групі, 10340 (50,3\%) - у III, $8268(20,2 \%)$ - у IV і $8215(19,4 \%)$ - V групі. Характерно, що найбільший приріст інтенсивності яйцекладки відзначений у бджолиних маток III групи, яким згодовували 2 мг цитрату $\mathrm{Co} / 0,3$ л цукрового сиропу порівняно як із контрольною групою $(50,3 \%)$, так і підготовчим періодом (117,5\%) і дещо менший (відповідно 41,9\% i 81,2\%) в II групі, яка отримувала 2 мг цитрату Ni.

Тоді як застосування в меншій дозі цитрату $\mathrm{Ni}$ в IV групі і поєднання $\mathrm{Ni}$ з Со в $\mathrm{V}$ дослідній групі характеризувалося нижчим приростом (20,2\% і 19,4\%) відкладених яєць, що може залежати від зниження дози, а також розглядатися як антагоністична взаємодія Ni на біологічний вплив Co, яке встановлено для інших елементів (Co-J; $\mathrm{Co-Zn})^{59}$. Тоді як згодовування самого цитрату Ni бджолиним сім'ям II групи викликало більш високий рівень приросту інтенсивності яйцекладки бджолиних маток за перший 12-добовий дослідний період (60\%) порівняно з підготовчим періодом, ніж у $\mathrm{V}$ дослідній групі $(38,9 \%)^{60,61}$.

Аналіз даних обліку яйцекладки маток у другому 12-добовому дослідному періоді свідчить про більш високу ії інтенсивність у сім'ях усіх (II-V) дослідних груп. Проте вищий рівень яйцекладки бджолиних маток у цей період встановлено в III (37,9\% від контролю і 162,3\% порівняно з підготовчим періодом) і IV (відповідно 58,2\% та 177\%) групах. Тоді як у II групі ці показники підвищувалися до 23,6\% і 121\%, а в $\mathrm{V}-13,5 \%$ і $73,7 \%$.

59 Величко В.О. Корекція антиоксидантного статусу сільськогосподарських тварин мікроелементами. Львів : СПОЛОМ, 2011. 76 с.

${ }^{60}$ Підгодівля бджіл і методи оцінки її ефективності. Методичні рекомендації / Р.С. Федорук та ін. Львів, 2016. 31 с.

${ }^{61}$ Интенсивность откладывания яиц пчелиными матками в весенний период при скармливании их семьям цитратов Со и Ni с сахарным сиропом / Р.С. Федорук та ін. Collection of works of scientific symposium with international participation "Zootechnycal science - an important factor for the european type of the agriculture». Moldova, Maximovca, 2016. C. 774-779. 


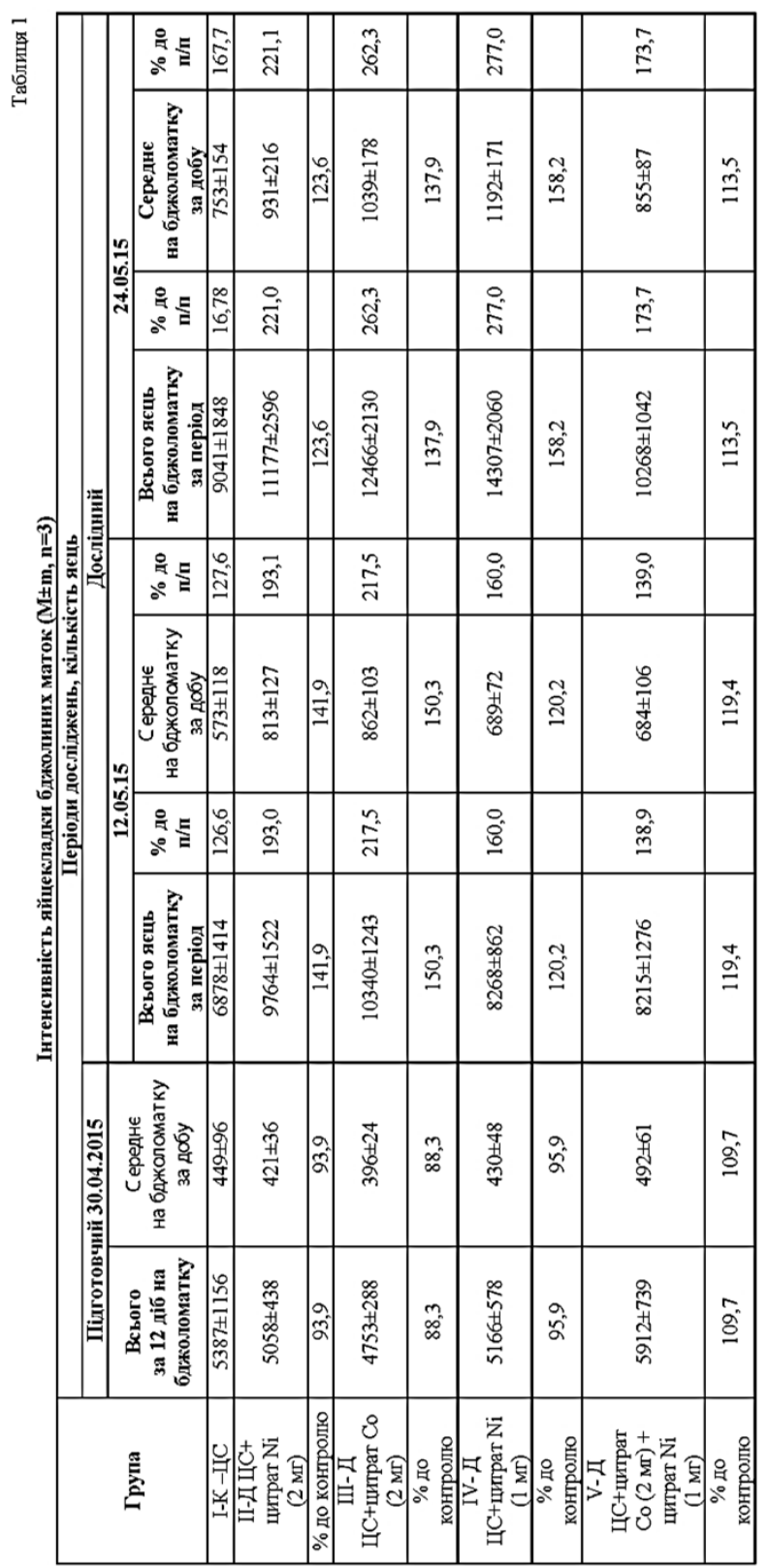


Отримані результати підтверджують припущення про можливість взаємного антагоністичного впливу Co i $\mathrm{Ni}$ на інтенсивність яйцекладки бджолиних маток, оскільки роздільне застосування цитратів Co (III гр.) і Ni (II i IV гр.) проявило високий рівень збільшення яйцекладки маток у II дослідний період.

Аналіз отриманих результатів середньої інтенсивності яйцекладки бджолиних маток за добу в підготовчий і дослідний періоди вказує на збереження зазначених для загальної кількості відкладених за період яєць відмінностей між контрольною і дослідними групами. Середня кількість відкладених маткою яєць за добу в підготовчий період коливалася від 396 у III групі до 492 шт. в V групі. У перший 12-добовий період згодовування цитратів Co i Ni вищий приріст кількості відкладених яєць відзначено в дослідних групах (38,9-117,5\%) порівняно 3 підготовчим періодом, оскільки інтенсивність підвищення середньої яйцекладки маток контрольної групи була найнижчою - 27,6\%. Середня кількість яєць, відкладених бджолиними матками за добу в другий дослідний період, у контрольній групі збільшилася до 753 і становила 67,7\%. Однак у IIIV дослідних групах їх кількість зросла більше ніж у 2 рази і становила 931, 1039 і 1192 шт. Менша інтенсивність відкладання яєць матками відзначена в V групі - 855, або 13,5\% від контролю.

Середня кількість відкладених яєць однією маткою на добу за 24-добовий дослідний період зберігала рівень відмінностей між контрольною і дослідними групами, зазначений для загальної кількості розплоду. Характерно, що середня кількість яєць, відкладених кожною бджолиною маткою II-IV груп, перевищувала цей показник підготовчого періоду в 2,2-2,7 рази, тоді як у контрольній i $\mathrm{V}$ дослідній - в 1,7 рази.

Установлені відмінності інтенсивності яйцекладки між контрольною i дослідними групами в перший i другий 12-добові періоди зберігаються й у цілому за дослідний період застосування добавок (рис. 1).

Кількість відкладених бджолиними матками яєць у дослідних групах перевищувала контрольну на $31,5 \%$ у II групі, 43,3\% - у III, $41,8 \%$ - y IV i $16,1 \%$ - y V групі, що вказує на більш високу ефективність роздільного застосування цитратів Сo i Ni.

Отримані результати досліджень указують на істотний стимулюючий вплив цитратів Co i $\mathrm{Ni}$ за роздільного їх застосування на інтенсивність яйцекладки бджолиних маток у весняний період. Комплексне застосування цитратів Co i Ni у період весняної підгодівлі бджіл характеризується меншим стимулюючим впливом на 
інтенсивність яйцекладки бджолиних маток, аніж роздільне їх згодовування ${ }^{62,63}$.

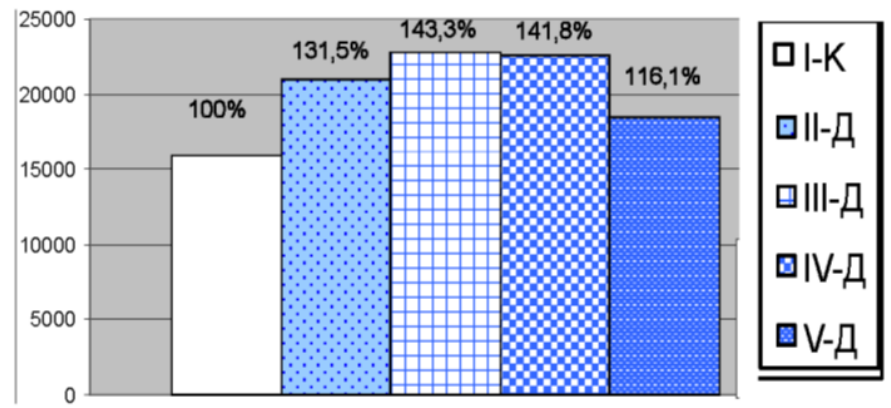

Рис. 1. Кількість відкладених ясць бджолиними матками за дослідний період, шт.

\section{4. Вплив цитратів Co i Ge на репродуктивну здатність бджолиних маток у весняний період}

Установлено, що уведення бджолиним сім'ям цитратів Co i Ge до сиропу весняної підгодівлі викликало підвищення інтенсивності яйцекладки бджолиних маток дослідних груп (табл. 2). У підготовчий період кількість відкладених яєць кожною бджолиною маткою контрольної та дослідних груп за 12 діб обліку коливалася від 2292 (IV група) до 2619 (III група) проти 2111 яєць у контролі. Упродовж перших 12 діб дослідного періоду їх кількість збільшилася до 4429 (39,7\% від контролю) у II групі, 5442 (71,7\%) - у III, 4250 (34,1\%) - IV групі. Характерно, що найбільший приріст інтенсивності яйцекладки відзначений у бджолиних маток III групи, яким згодовували 60 мкг цитрату $\mathrm{Ge} / 0,3$ л цукрового сиропу порівняно як з контрольною групою (71,7\%), так і підготовчим періодом (107,8\%). Тоді як застосування цитрату Со в II групі і поєднання Co i Ge y IV дослідній групі характеризувалося нижчим приростом (39,7\% і 34,1\%) відкладених яєць.

${ }^{62}$ Pashchenko A. Innovative methods of preservations of the bees health based on Cobalt and Nickel nanocitrate. III Lodzka Miedzynarodowa Konfenrecija Pszczelarska «Pszczelarstwo Europejskie - Kluczowe Aspekt Nowoczesnej Gospodarki Pasiecznej», Tyszyn, 15-1 listopada 2018. Tyszyn, 2018. P. 85-86.

63 Пащенко А.Г. Мікроелементи та ліпіди тканин і продукції бджіл за підгодівлі цитратами Co i Ni та борошном сої : автореф. дис. ... канд. вет. наук : 03.00.13. Львів, 2019. 24 с. 
Аналіз даних обліку яйцекладки маток у наступному 12-добовому дослідному періоді (III етап) свідчить про вищу їх інтенсивність у сім'ях II і III дослідних груп за умов роздільної підгодівлі цитратами Co i Ge. Щодо наступного IV етапу, то встановлено вищий рівень яйцекладки бджолиних маток у III $(39,6 \%$ від контролю і $24,0 \%$ порівняно з підготовчим періодом) і ІІ (відповідно 24,4\% та 6,0\%) групах. Тоді як у заключний період (V етап) кількість яєць за 12 діб збільшилася до 15503 (12,5\% від контролю) у II групі, 15850 (15,0\% від контролю) - у III, 14844 (7,7\% від контролю) - IV групі.

Аналіз отриманих результатів загальної кількості відкладених яєць за обліковий період указує на збереження зазначених для загальної кількості відкладених за період яєць відмінностей між контрольною і дослідними групами. Кількість відкладених маткою яєць коливалася від 35335 у II групі до 45223 шт. у III групі. Менша інтенсивність відкладання яєць матками відзначена в IV групі - 38896 шт. за обліковий період. Отримані результати підтверджують припущення про можливість впливу $\mathrm{Co}$ i $\mathrm{Ge}$ на інтенсивність яйцекладки бджолиних маток, оскільки як роздільне, так і комплексне застосування цитратів Co i Ge проявило високий рівень збільшення яйцекладки маток у дослідний період.

Очевидно, вищий рівень яйцекладки маток дослідних груп може підтримуватися як збільшенням умісту біологічно активних компонентів у маточному молочку бджіл-годувальниць дослідних груп від стимулюючого впливу цитратів Co i Ge на обмін речовин у їх організмі, так і збереженням високої активності репродуктивної системи маток цих бджолосімей після стимулюючого впливу цитратів Сo i $\mathrm{Ge}$ у дослідний період.

Таким чином, застосування стимулюючої підгодівлі у бджільництві сприяє збільшенню життєздатності, резистентності та репродуктивної здатності бджолиних сімей. Також це чинить позитивний вплив на біологічний і фізіологічний стан організму бджіл, збільшуючи живу масу, посилюючи ріст, розвиток, сприяючи кращій фізіологічній підготовці бджіл до зимівлі, що в кінцевому підсумку дає змогу значно скоротити витрату вуглеводного і протеїнового кормів під час їх переробки і осіннього нарощування. 


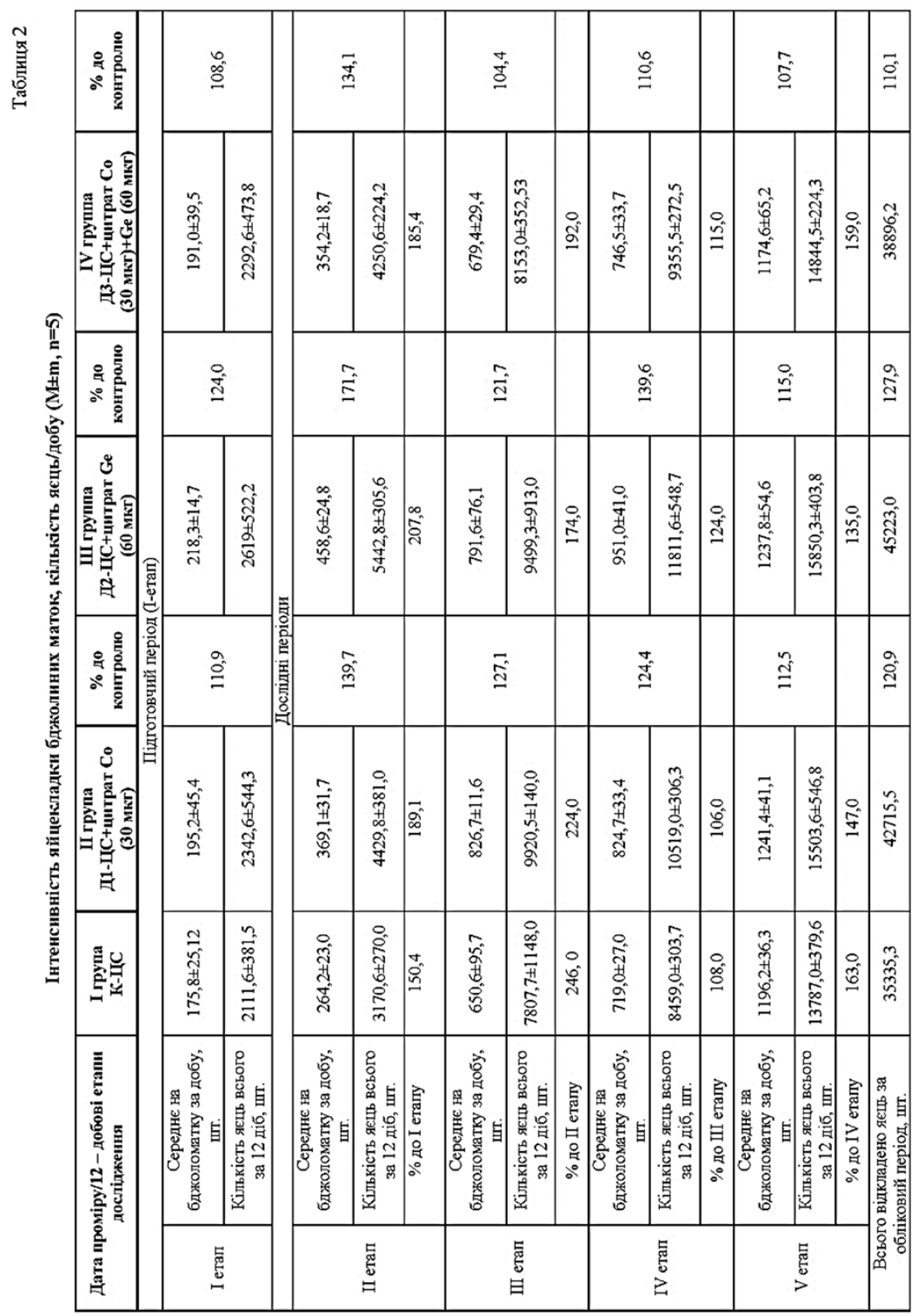




\section{ВИСНОВКИ}

1. Додавання цитратів Co $\mathrm{i} \mathrm{Ni}$, отриманих методом нанотехнології, до сиропу весняного підгодівлі медоносних бджіл підвищує інтенсивність відкладання яєць бджолиними матками на 13,5-58,2\%, що більш виражено в другому 12-добовому періоді.

2. Цитрат Со характеризується високим стимулюючим впливом у дозі 2 мг/0,3 л цукрового сиропу, а цитрат $\mathrm{Ni}$ - у кількості 1 і 2 мг/0,3 л сиропу.

3. Комплексне застосування цитратів Co $(2$ мг) i $\mathrm{Ni}(1$ мг) iз цукровим сиропом за весняної підгодівлі медоносних бджіл характеризується меншим стимулюючим впливом на інтенсивність відкладання яєць матками бджіл, аніж роздільне їх застосування.

4. З'ясовано особливості впливу різних доз цитратів Со (30 мкг) i Ge (60 мкг), що отримані 3 використанням нанотехнології, 3 додаванням цих сполук до цукрового сиропу бджолам у весняний період на вміст окремих мінеральних елементів у тканинах організму медоносних бджіл та інтенсивність яйцекладки бджолиних маток. Визначено біологічно ефективну кількість Co i Ge цитратів для введення до компонентів стимулюючої підгодівлі бджолиним сім'ям у весняний період їх живлення.

\section{АНОТАЦІЯ}

Застосування цитратів $\mathrm{Co}$, Ni та Ge у живленні бджолиних сімей підвищує життєздатність бджіл і репродуктивну функцію бджолиних маток. Установлено, що уведення бджолиним сім'ям цитратів Co, Ni та $\mathrm{Ge}$ до сиропу весняної підгодівлі викликало підвищення інтенсивності яйцекладки бджолиних маток дослідних груп. Характерно, що найбільший приріст інтенсивності яйцекладки відзначений у бджолиних маток, яким згодовували роздільно цитрати $\mathrm{Co}, \mathrm{Ni}$ та $\mathrm{Ge}$ iз цукровим сиропом. Комплексне застосування цитратів Co i $\mathrm{Ni}$ iз цукровим сиропом за весняної підгодівлі медоносних бджіл характеризується меншим стимулюючим впливом на інтенсивність відкладання яєць матками бджіл, аніж роздільне їх застосування. Проте комплексне застосування цитратів Co i Ge проявило високий рівень збільшення яйцекладки маток у дослідний період. Очевидно, вищий рівень яйцекладки маток дослідних груп може підтримуватися збільшенням умісту біологічно активних компонентів у маточному молочку бджіл-годувальниць дослідних груп від стимулюючого впливу цитратів цих мікроелементів на обмін речовин у їхньому організмі.

Стимулюючий вплив мінеральної добавки на основі цитратів $\mathrm{Co}, \mathrm{Ni}$ та Ge на інтенсивність яйцекладки бджолиних маток і силу бджолиної сім’і використано для наукового обгрунтування пропозицій щодо 
вдосконалення компонентів підгодівлі медоносних бджіл. Отримані результати використані для оптимізації компонентів підгодівлі медоносних бджіл і обгрунтування пропозицій виробництва 3 підвищення плодючості їх маток у весняний період.

\section{ЛІТЕРАТУРА}

1. Скальный А.В. Химические элементы в физиологии и экологии человека. Москва : ОНИКС 21 век ; Мир, 2004. 216 с.

2. Скальний А.В., Рудаков И.А. Биоэлементы в медицине. Москва : Мир, 2004. 272 с.

3. Kabata-Pendias A., Pendias H. Trace elements in soils and plants ; 3rd ed. CRC Press, 2001. 403.

4. Effect of feeding bees with sugar solution (1:1) and Isosweet on some qualitative parameters of Honey / I. Jeliazkova et al. Agrarian sciences Trematology. 2002. № 2. P. 300-303.

5. Шамро Л.П., Шамро Т.М. Біологічні особливості робочих бджіл за умов зимівлі бджолиних сімей на різних кормах. Вісник Полтавської державної аграрної академії. 2013. № 2. С. 70-72.

6. Скальная М.Г., Дубовой Р.М., Скальный А.В. Химические элементы - микронутриенты как резерв восстановления здоровья жителей России. Оренбург, 2004. 239 с.

7. Кучинский М.П. Биоэлементы и сохранение здоровья и продуктивности животных. Минск, 2006. 264 с.

8. Федорук Р.С., Ковальчук І.І., Гавраняк А.Р. Фактори формування імунітету медоносних бджіл. Біологія тварин. 2009. Т. 11(1-2). C. 83-90.

9. Glinski, Z., Grzegorczyk, K. Hemolymph proteins of the honeybee (Apis mellifera L.) from apiaries differing by the level of pollution with heavy metals. Ann. UMCS. DD. 1995.V. 50. P. 241-248

10.Zidorova, K. A., Kalashnikov, M. V. Mineral composition of the hemolymph of bees in the brood Varroa. Beekeeping. 2014. V. 2. P. 22-23.

11. Губайдуллин Н. М. Стимулирующие подкормки, аэроионизация и продолжительность жизни пчел. Пчеловодство. 2008. № 10. C. $12-13$.

12. Шагун Л.А. Минеральные подкормки и физиологическое состояние пчел. Пчеловодство. 1982. № 8. С. 15-16.

13. Жулай В.С. Особливості білково-мінерального складу меду та біохімічне обгрунтування комплексної кормової добавки : автореферат. дис. ... канд. с.-г. наук : 06.02.04. Київ, 2000. 22 с.

14. Abenavoli A., Montagna M., Malgaroli A. Calcium: The common theme in vesicular cycling. Nature Neurosei. 2001. V. 4(2). P. 117-118. 
15. Winston Mark L. The Biology of the Honey Bee. London : Harvard University Press, 1991. $281 \mathrm{p}$.

16. Лебедев В.И., Билаш Н.Г. Питательная ценность кормов и подкормка семей. Пчеловодство. 1995. № 1. С. 16-20.

17. Самотин В. Профилактика нарушения обмена микроэлементов у животных. Москва : Колос, 1981. 143 с.

18. Морозова Л.М. Химические элементы в организме человека : справочные материалы. Архангельск : ПГУ, 2001. 45 с.

19. Скальный А.В. Микроэлементозы человека (диагностика и лечение). Практическое руководство. Москва, 2001. 96 с.

20. Скальный А.В. Микроэлементы: бодрость, здоровье, долголетие. Москва : Эксмо-Пресс, 2010. 288 с.

21. Effect of feeding bees with sugar solution (1:1) and Isosweet on some qualitative parameters of Honey / I. Jeliazkova et al. Agrarian sciences Trematology. 2002. V. 2. P. 300-303.

22. Буртов Б.Я. Влияние кобальта на размножение пчел. Сельское хозяйство Северного Кавказа. 1958. № 2. С. 77-79.

23. Буртов Б.Я. Кобальт и продуктивность пчел. Пчеловодство. 1961. № 10. С. 22.

24. Авцын А.П., Жаворонков А.А., Рим М.А. Микроэлементозы человека, этиология, классификация, органопатология. Москва : Медицина, 1991. 496 с.

25. Пашаян С.А., Столбов Н.М. Кормовые добавки для пчел Пчеловодство. 2008. № 7. С. 14-15.

26. Голоскоков В.Г. Влияние микроелементов на морфологофизиологические показатели и продуктивность пчел. Ульяновск, 1981. C. $10-14$.

27. Anderson S.P.T. Nickel and cobalt: Their physiological action on the animal organism. J. Anat. Physiol. 1983. V. 17. P. 89-123.

28. Nemery, B., Lewis, C.P.L., Demedts, M. Cobalt and possible oxidant-mediated toxicity. Sci. Total Environ. 1994. V. 150. P. 57-64.

29. Турко Я.І. Вплив нанокобальту на антиокислювальної системи організму щурів за гострого токсикологічного експерименту. Науковий вісник Львівського начіонального університету ветеринарної медицини та біотехнологій ім. 3.С. Гжицького. 2015. Т.1 7. № 1(61). С. 194-200.

30. Ушкалов В.О., Турко Я.І. Стан антиокислювальної системи організму щурів за дії нанокобальту в хронічному токсикологічному експерименті. Науковий вісник Львівського національного університету ветеринарної медицини та біотехнологій імені С.3. Гжицького. 2016. T. 18. № 1(65). C. 238-243.

31. Роль мікроелементів у життєдіяльності тварин / М.О. Захаренко та ін. Ветеринарна медицина України. 2004. № 2. С. 13-16. 
32. Белецкий Е.М., Кулибаба Р.А., Владыкин К.П. Никель. Польза и вред для живых организмов. Вісник ЦНЗ АПВ Харківської області. 2012. № 12. C. 263-283.

33. Palynological, physico-chemical and aroma characterization of Sicilian honeys / F. Aboud et al. Journal of ApiProduct and ApiMedical Science. 2011. V. 3(4). P. 164-173.

34. Diet effects on honeybee immunocompetence / C. Alaux et al. Biology Letters. 2010. V. 6. P. 562-565.

35. Miracle Cure Organic Germanium, 1980. URL: http://www.organicgermanium.net/images/dr_asai_book.pdf.

36. Shyy Hwa Tao Hazard, Bolger M. Assesment of Germanium supplements. Regulatory toxicology and pharmacology. 1997. Vol. 25. P. 211-219.

37. Jain K.K. Nanomedicine: application of nanobiotechnology in medical practice. Med. Princ. Pract. 2008. V. 17(2). P. 89-101.

38. Кодесь Л.Г., Пулинец Е.К. Слагаемые качества маток. Пчеловодство. 2004. № 5. С. 14-15.

39. Кодесь Л.Г., Шаров М.А., Коптева Е.Н. Выращивание пчелиного и трутневого расплода. Пчеловодство. 2012. № 6. С. 18-19.

40. Liviu A.M., Otilia B., Melinda T. The Effect of Plant Supplements on the Development of Artificially Weaken Bee Families. Animal Science and Biotechnologies. 2010. V. 43(1). P. 457-503.

41. Левченко I.А. Стосунки між матками і робочими бджолами. Український пасічник. 1999. № 3. С. 10-11.

42. Nutritional status influences socially regulated foraging ontogeny in honey bees / A. Toth et al. Journal of Experimental Biology. 2005. V. 208. P. 4641-4649.

43. Toth A.L., Robinson G.E. Worker nutrition and division of labour in honeybees. Anim. Behav. 2005. V. 69. P. 427-435.

44. Biesmeijer J.C., Klaus Hartfelder K., Imperatriz-Fonseca V.L. Stingless bees: biology and management. Apidologie. 2006. P. 121-123.

45. Biologically active compounds from different herbs used as additive in honeybee feeding / O. Bobiş et al. USAMV Cluj Bull. 2009. V. 66(1-2). P. 231-236.

46. Пшеславський А. Не только количество, но и качество пчел определяет успех в пчеловодстве. Пасічник. 2009. № 7(64). С. 19-21.

47. Heifetz Y. The Drosophila seminal fluid protein Acp26Aa stimulates release of oocytes by the ovary. Curr. Biol. 2000. V. 10. P. 99-102.

48. Аветисян Г.А., Черевко Ю. . Пчеловодство. Москва : Академия, $2001.320 \mathrm{c}$.

49. Zhelyazkova I. Honeybees - bioindicators for environmental quality. Bulg. J. Agric. Sci. 2012. V. 18. P. 435-442. 
50. Нестерводський В.А. Організація пасік і догляд за бджолами. Київ : Урожай, 1966. 396 с.

51. Effects of Long Distance Transportation on Honey Bee Physiology / A. Kiheung et al. Psyche. 2012. V. 29. P. 9.

52. The role of "Apispir+Zn" biostimulator in increasing of productivity of Apis mellifera bee colonies / V. Cebotari et al. Scientific Papers. Series Animal Science. 2013. V. 59. P. 103-107.

53. Брандорф А.З., Ивойлова М. Яйценосность маток в оценке медопродуктивности и зимостойкости семей. Пчеловодство. 2012. № 6. С. $16-18$.

54. Дружбяк А. Якість зимівлі бджолиних сімей. Украӥнський пасічник. 2008. № 1. С. 25.

55.Панков Д.М. Комплексный подход к содержанию пчел. Пчеловодство. 2013. № 6. С. 12-13.

56. Сафиуллин Р.Р. Совершенствование технологии содержания и использования пчелиных семей в условиях Татарстана : автореф. дис. ... канд. с.-х. наук. Рыбное, 2005. 28 с.

57. Дегтерев В.Г. Яйценоскость пчелиных маток и температурный режим в гнезде кассетных ульев, установленных в кочевом павильоне. Пчеловодство холодного и умеренного климата : материаль IV Международной научно-практической конферениии. Псков, 2016. C. 23-26.

58. Методологія та організація наукових досліджень у тваринництві : посібник / за ред. I.I. Ібатулліна, О.М. Жукорського. Київ : Аграрна наука, 2017. 328 с.

59. Величко В.О. Корекція антиоксидантного статусу сільськогосподарських тварин мікроелементами. Львів : СПОЛОМ, $2011.76 \mathrm{c}$.

60. Підгодівля бджіл і методи оцінки їі ефективності. Методичні рекомендації / Р.С. Федорук та ін. Львів, 2016. 31 с.

61. Интенсивность откладывания яиц пчелиными матками в весенний период при скармливании их семьям цитратов Со и $\mathrm{Ni} \mathrm{c}$ сахарным сиропом / Р.С. Федорук и др. Collection of works of scientific symposium with international participation "Zootechnycal science - an important factor for the european type of the agriculture». Moldova. Maximovca, 2016. C. 774-779.

62. Pashchenko A. Innovative methods of preservations of the bees health based on Cobalt and Nickel nanocitrate. III Lodzka Miedzynarodowa Konfenrecija Pszczelarska «Pszczelarstwo Europejskie - Kluczowe Aspekt Nowoczesnej Gospodarki Pasiecznej», Tyszyn 15-1 listopada 2018. Tyszyn, 2018. C. 85-86. 
63. Пащенко А.Г. Мікроелементи та ліпіди тканин і продукції бджіл за підгодівлі цитратами Со і $\mathrm{Ni}$ та борошном сої : автореф. дис. ... канд. вет. наук : 03.00.13. Львів, 2019. 24 с.

\section{Information about the authors:}

Kovalchuk I. I.,

Doctor of Veterinary Sciences, Senior Scientific Worker, Head of the Laboratory of Environmental Physiology and Product Quality Institute Biology of Animals of the National Academy of Agrarian Sciences of Ukraine 38, V. Stusa str., Lviv, 79034, Ukraine

Kykish I. B., Postgraduate at the Laboratory of Environmental Physiology and Product Quality Institute Biology of Animals of the National Academy of Agrarian Sciences of Ukraine 38, V. Stusa str., Lviv, 79034, Ukraine

Kaplunenko V. H., Doctor of Technical Sciences,

Chief

LLC «Nanomaterials and Nanotechnologies»

27, Vasylkivska str., Kyiv,03022, Ukraine 